\title{
МІЖНАРОДНО-ПРАВОВЕ РЕГУЛЮВАННЯ ДІЯЛЬНОСТІ НЕУРЯДОВИХ ОРГАНІЗАЦІЙ
}

\author{
INTERNATIONAL LEGAL REGULATION OF THE NON-GOVERNMENTAL \\ ORGANIZATIONS ACTIVITIES
}

\author{
Xap O.F., \\ аспірант, \\ асистент кафедри політології та міжнародних відносин \\ Національного університету «Львівська політехніка»
}

\begin{abstract}
У статті проаналізовано міжнародну правосуб'єктність і міжнародно-правове регулювання міжнародних неурядових організацій. Виявлено, що міжнародні неурядові організації посідають пріоритетне місце в процесі правоутворення та правореалізації. Визначено доцільність здійснення нормативно-правового регулювання міжнародної діяльності НУО на двох рівнях, таких як міжнародно-правове регулювання й саморегуляція. Досліджено сутність та ознаки таких категорій, як «суб'єкти міжнародного права» й «міжнародна правосуб'єктність». Визначено, що МНУО володіють спеціальною міжнародною правосуб'єктністю, яка виражається в її правозастосовувальному характері. У свою чергу, проаналізовано низку документів, у яких порушувалося питання щодо кодифікування правил поведінки стосовно визнання правосуб'єктності МНУО на міжнародному рівні, зокрема Конвенцію про захист прав людини і основоположних свобод, Європейську конвенцію про визнання юридичними особами міжнародних неурядових організацій і Фундаментальні принципи щодо статусу неурядових організацій у Європі. Як показав аналіз, міжнародно-правове регулювання діяльності конкретних МНУО здійснюється міжнародним правом частково, інакше кажучи, фрагментарно регулюється через спеціальні міжнародно-правові договори. Отже, розглянуто деякі чинні правові норми в конкретних сферах діяльності, зокрема в міжнародному гуманітарному, екологічному та кримінальному праві, а також дотичних до захисту прав людини. Одним із важливих аспектів міжнародно-правового регулювання діяльності МНУО визначено міжнародно-правову відповідальність, яка виникає в сучасному міжнародному праві у зв'язку з правопорушеннями, що їх здійснюють будь-які суб'єкти міжнародного права. Також проаналізовано кодекси поведінки, які з метою регулювання діяльності МНУО самостійно розробляють і приймають, зокрема Кодекс етики та поведінки Всесвітньої асоціації неурядових організацій і Хартію відповідальності міжнародних неурядових організацій.
\end{abstract}

Ключові слова: міжнародні неурядові організації, міжнародне право, правосуб'єктність, міжнародні норми, міжнародно-правова відповідальність.

The international legal personality and international legal regulation of international non-governmental organizations are analyzed in the article. It is revealed that international non-governmental organizations occupy a priority place in the process of law-making and law implementation. The expediency of implementing the legal regulation of the NGO's international activity at two levels has been determined: international legal regulation and self-regulation. The nature and features of such categories as "subjects of international law" and "international legal personality" are investigated. It is determined that INGOs have a special international legal personality, which is expressed in its law enforcement nature. In turn, a number of documents were analyzed which raised the issues of codifying the rules of conduct for the recognition of the legal personality of INGOs at international level, in particular, the Convention for the Protection of Human Rights and Fundamental Freedoms, the European Convention on the Legal Entity of International Non-Governmental Organizations and the Fundamental Principles for the Status of Non-governmental Organizations in Europe. As the analysis has shown, the international legal regulation of the activities of specific INGOs is carried out by international law in part, in other words, it is fragmented through special international legal treaties. In this way, some current legal norms are considered in specific areas of activity, in particular, in international humanitarian, environmental and criminal law, as well as those related to the protection of human rights. One of the important aspects of the international legal regulation of the activities of INGOs is the international legal responsibility that arises in modern international law in connection with offenses committed by any subject of international law. In this article it is also analyzed the codes of conduct that are independently developed and adopted to regulate the activities of INGOs, in particular, the Code of Ethics and Conduct of the World Association of NonGovernmental Organizations and the Charter of Accountability of International Non-Governmental Organizations.

Key words: international non-governmental organizations, international law, legal personality, international norms, international legal responsibility.

Постановка проблеми. Визначення суб'єктів міжнародного права є однією 3 найважливіших i найскладніших проблем на сучасному етапі розвитку міжнародно-правової науки. Очевидно, що міжнародні неурядові організації (далі - МНУО) посідають вагоме місце серед величезної кількості учасників міжнародних правовідносин, адже $є$ однією з форм міжнаціонального спілкування між різними народами та націями, проте, незважаючи на цей факт, у світовому науковому співтоваристві й досі триває дискусія щодо їхньої міжнародної правосуб'єктності. Тому, зважаючи на постійне збільшення кількості МНУО та активізацію їхньої ролі у вирішенні міжнародних проблем, питання про міжнародну правосуб'єктність і міжнародноправове регулювання цих організацій набуває все 
більшої актуальності в сучасній як міжнародноправовій, так і політичній науці.

Аналіз останніх досліджень і публікацій. Стрімке збільшення сфер діяльності й масштабне функціонування МНУО в сучасній глобальній системі викликає дедалі більшу наукову зацікавленість. Отже, вивчення міжнародно-правового регулювання діяльності МНУО необхідне для дослідження розвитку міжнародних відносин загалом. Низка зарубіжних і вітчизняних науковців досліджувала цю проблематику. Зокрема, О. Тарасов виокремив пріоритетну роль МНУО в процесі правоутворення та правореалізації [2]. Сутність та ознаки категорій «суб'єкти міжнародного права» й «міжнародна правосуб'єктність» досліджували I. Килимник, А. Домбровська, В. Репецький, Н. Камінська, О. Делінський, М. Грабинський, Т. Цимбрівський [3-8]. Міжнародну правосуб'єктність МНУО вивчали I. Білорус, С. Подшибякін та У. Ільницька [9-11]. А. Мазов трактував міжнародно-правову відповідальність важливим аспектом у механізмі міжнародно-правового регулювання діяльності МНУО [24]. У статті проаналізовано міжнародні документи: конвенції, хартії та кодекси, за допомогою яких здійснюється міжнародно-правове регулювання діяльності МНУО.

Формулювання цілей статті (постановка завдання). Метою статті є дослідження міжнародно-правового регулювання діяльності МНУО.

Виклад основного матеріалу дослідження. Аналізуючи провідні тенденції глобальної політики, які зумовлені процесами глобалізації, дослідниця Л. Чернявська виокремлює чотири важливі світові тенденції, що здійснюють значний вплив на стрімку активізацію НУО у ХХ - ХХІ ст., a саме: «тенденція до розмивання кордонів, як між внутрішньою, так і зовнішньою політикою та економікою; втрата державами монополії на роль головного вершителя долі міжнародної політики; розширення кола безпосередніх учасників міжнародних політичних відносин; демократизація світового політичного процесу» $[1$, с. 8$]$.

МНУО, інтегруючи міжнародну громадську думку, є інституційними суб' єктами глобального громадянського суспільства. У свою чергу, світова думка впливає на учасників міжнародних відносин, змушуючи їх виконувати вже чинні правила та норми поведінки, а в подальшому активізує процес створення нових міжнародних норм права. Цей процес можна повністю відстежити на різних етапах механізму міжнародно-правового регулювання діяльності НУО. Виходячи із цього, О. Тарасов виокремлює пріоритетну роль МНУО в процесі правоутворення та правореалізації. Щодо процесу правоутворення, то МНУО впливають на встановлення прогалин у чинному міжнародному праві; розроблення проектів резолюцій і конвенцій; уне- сення проектів у відповідні органи держав і міжнародних міжурядових організацій (далі-ММУО) та вимагають їх детального розгляду; створення за допомогою світової громадської думки моральнополітичних i, якщо змога, матеріальних умов для підписання й ратифікації міжнародних договорів. Місце МНУО в процесі правореалізації проявляється в громадському контролі за виконанням державами своїх зобов'язань; інформуванні світового співтовариства, насамперед ООН, про факти порушення подібних зобов'язань; розробленні та внесенні пропозицій у відповідні органи держав і ММУО з подолання кризових ситуацій; створенні умов для найшвидшого припинення міжнародноправових порушень [2, с. 9].

Нормативно-правове регулювання міжнародної діяльностіНУО доцільноздійснювати в розрізі двох рівнів: 1) міжнародно-правове регулювання, яке включає в себе правовий статус, міжнародні норми, міжнародно-правову відповідальність; 2) саморегуляція (внутрішне право, кодекси поведінки).

Перш ніж перейти до з'ясування правового статусу НУО, потрібно згадати визначення таких категорій, як «суб'єкти міжнародного права» та «міжнародна правосуб'єктність». Досліджуючи праці сучасних науковців, можемо виокремити деякі трактування цих дефініцій. Суб'єкти міжнародного права - це учасники міжнародних відносин, які володіють міжнародними правами й обов'язками, здійснюють їх на основі міжнародного права та несуть у необхідних випадках міжнародно-правову відповідальність [3]; утворення, незалежні один від одного, які не підпорядковані у сфері міжнародних відносин політичній владі [4]; учасники міжнародних правовідносин, яким притаманні елементи міжнародної правосуб'єктності [5]; носії міжнародних прав та обов'язків згідно 3 нормами міжнародного права, що можуть вступати в міжнародні (міжвладні) публічні відносини [6]. Міжнародну правосуб'єктність науковці трактують як якісну характеристику статусу суб'єкта міжнародних правовідносин, що виражає його здатність самостійно брати участь у цих правовідносинах, підпорядковуватися нормам міжнародного права та володіти міжнародними правами й обов'язками [7]; міжнародно-правову категорію, що $є$ якісною характеристикою суб'єкта міжнародного права, яка розглядається як сукупність елементів: правоздатність, дієздатність і деліктоздатність [8].

Аналізуючи ММУО, бачимо, що вони володіють міжнародною правосуб'єктністю, яка є установленою міжнародними угодами, інакше кажучи, установчими актами цих організацій. 3 огляду на це, правосуб'єктність ММУО є вторинною. Отже, ММУО, членами яких є держави, мають найбільш урегульований міжнародно-правовий статус.

Щодо правосуб'єктності МНУО, здійснивши дослідження наукової літератури, можемо ствер- 
джувати, що погляди науковців розходяться і $\epsilon$ суперечливими. Тому сьогодні виділено два основні підходи, яких дотримуються ті чи інші науковці: 1) МНУО є суб’єктами не міжнародного права, а міжнародних правовідносин; 2) для МНУО, статут і діяльність яких не суперечить основним принципам міжнародного права, визнається обмежена міжнародна правосуб'єктність у межах консультативних відносин із ММУО, а також у визначених межах права міжнародних організацій [9, с. 27]. МНУО фактично є об'єднанням національних громадських організацій двох чи більше держав 3 метою досягнення цілей у тій чи іншій сфері в міжнародному масштабі. МНУО відрізняються від ММУО своєю юридичною природою, зокрема за суб'єктами утворення та природою походження іхніх установчих актів. Виходячи із цього, розуміємо, що статути МНУО відрізняються від статутів ММУО тим, що не є міжнародними договорами. МНУО не можуть створювати норми міжнародного права, тому, на відміну від ММУО, не володіють усіма елементами міжнародної правосуб'єктності, які перелічені вище [10].

МНУО отримують консультативний статус при ММУО, відповідно, мають певні права й обов' язки відповідно до міжнародних договорів. Тому необхідно визнати, що вони беруть участь у міжнародних відносинах, урегульованих міжнародним правом. 3 огляду на це, можемо стверджувати, що МНУО володіють спеціальною міжнародною правосуб'єктністю, яка виражається в пї правозастосовувальному характері. Таку спеціальну міжнародну правосуб'єктність у міжнародноправовій літературі називають функціональною, що відрізняється від універсальної (загальної), яка притаманна лише державі, та галузевої, якою володіють ММУО. Міжнародну правосуб' єктність МНУО можна також називати спеціальною, частковою, фрагментарною або факультативною, яка виключає здатність до нормотворення, проте має виключно правозастосовувальний характер [11].

Міжнародне співтовариство намагається в той чи інший спосіб урегулювати питання правосуб'єктності МНУО. Зокрема, у 1950 році в Свропі прийнято Конвенцію про захист прав людини $i$ основоположних свобод, яка стала основним каталізатором законотворчого процесу щодо громадських організацій у європейських країнах. Згідно зі ст. 11 цієї Конвенції, «кожен має право на свободу мирних зібрань і свободу об'єднання з іншими особами, включаючи право створювати профспілки та вступати до них для захисту своїх інтересів» [12].

24 квітня 1986 року (Страсбург) прийнято Свропейську конвенцію про визнання юридичними особами міжнародних неурядових організацій. У статті 1 цього документа зазначено, що Конвенція застосовується до асоціацій, фондів, приватних інститутів, які охоплюються поняттям «неурядова організація» й відповідають загальним вимогам (ознакам), а саме: мають носити некомерційний (неприбутковий) характер; бути заснованими й діяти відповідно до законодавства своєї країни (сторони); мають реальні організаційні структури у своїй державі або за кордоном; поширюють свою діяльність мінімум ще на дві країни; мають законну штаб-квартиру на території сторони, а управлінські та контрольні органи - на території цієї держави або іншої сторони [13].

Отже, відповідна Конвенція є першою найбільш вдалою спробою кодифікувати правила поведінки щодо визнання правосуб'єктності МНУО на міжнародному рівні. Проте цей документ має суттєвий недолік, оскільки учасниками цієї конвенції є лише 11 держав (серед них - Австрія, Бельгія, Великобританія, Нідерланди, Франція, Швейцарія тощо), а цей факт свідчить про те, що кількість держав-учасників, які визнають правосуб'єктність МНУО, є обмеженою.

Ще одним важливим документом, який визначає статус НУО, є Фундаментальні принципи щзодо статусу неурядових організачій у Свропі. Цей документ прийнятий учасниками багатосторонньої зустрічі, яка організована Радою Свропи в Страсбурзі 5 липня 2002 року. У цьому документі вперше здійснено систематизацію основних європейських стандартів у галузі міжнародно-правового регулювання діяльності НУО, серед них такі: НУО включають об'єднання або організації, створені як окремими особами (фізичними або юридичними), так і групами таких осіб; НУО можуть бути як неформальними об'єднаннями або організаціями, так й об'єднаннями або організаціями, які мають правосуб'єктність; НУО можуть бути національними й міжнародними й за складом, i за сферою діяльності; НУО повинні мати право на свободу висловлення поглядів і будь-які інші права та свободи, що мають гарантії в міжнародних або регіональних договорах і можуть належати таким організаціям; НУО не підлягають управлінню 3 боку органів державної влади; НУО, які мають правосуб'єктність, повинні мати такі самі права, що зазвичай належать іншим юридичним особам, $\mathrm{i}$ на них повинні поширюватися такі самі обов'язки та санкції у сфері адміністративного, цивільного та кримінального права, що зазвичай застосовуються до таких юридичних осіб; НУО повинні представляти щорічний звіт своїм членам чи директорам щодо їхніх рахунків і діяльності [14].

Міжнародно-правове регулювання діяльності конкретних МНУО здійснюється міжнародним правом частково, інакше кажучи, фрагментарно регулюється через спеціальні міжнародно-правові договори. Так як багато міжнародних договорів містять норми, які безпосередньо регулюють діяльність НУО, то необхідно розглянути деякі чинні правові норми в конкретних сферах діяльності. 
Отже, зможемо прослідкувати регулювання діяльності МНУО в різних галузях міжнародного права.

1. Міжнародне гуманітарне право. Зокрема, найбільш широкий правовий статус має Міжнародний комітет Червоного Хреста (далі - МКЧХ), відповідно до Женевських конвениій про захист жертв збройних конфліктів (1949 рік). Така ситуація склалася в силу історичних подій, оскільки МКЧХ зробив вагомий внесок у захист жертв війни.

Загалом можна виокремити чотири аспекти статусу суб'єкта міжнародного права, якими користується МКЧХ:

- nо-перше, міжнародна правосуб'єктність універсального типу, яка визнається Женевськими конвенціями 1949 року та Додатковими протоколами до них 1977 року (така правосуб'єктність дає можливість МКЧХ виконувати всі необхідні дії з метою ефективного захисту жертв війни та інші функції, визнані за ним цими документами, а так як Женевські конвенції 1949 року ратифікували 194 держави, то таке визнання має універсальний характер);

- nо-друге, міжнародна правосуб'єктність визнанаООН,яканадалаМКЧХстатусспостерігача при Генеральній Асамблеї ООН (сьогодні МКЧХ є єдиною МНУО МКЧХ, яка має такий статус);

- no-mpeme, консультативний статус при Економічній і Соціальній Раді ООН (ЕКОСОР) та інших міжнародних організаціях;

- по-четверте, міжнародна правосуб'єктність, визнана договорами про статус МКЧХ та іншими договорами зі спеціальних питань, які він укладає 3 державами та міжнародними організаціями [15].

Ще одним документом є Оттавська конвенція (Конвенція про заборону застосування, накопичення запасів, виробництво й передачу протипіхотних мін і про їх знищзення, 1997 рік), яка затверджує загальну відповідальність держав, ООН і НУО, у тому числі Міжнародний комітет Червоного Хреста, національних товариств Червоного Хреста й Червоного Півмісяця, сприяти зусиллям щодо догляду та реабілітації, соціальної та економічної реінтеграції осіб, які постраждали від мін, і здійснювати програми інформування про мінну небезпеку [16].

2. Захист прав людини. Конвенція про права дитини від 20.11.1989 в ст. 22 затверджує необхідність співпраці держав і НУО в сфері захисту дітей-біженців.

Європейська конвенція про здійснення прав dimeй від 25.01.1996 в ст. 17.3 зазначає «про можливість участі міжнародних і національних НУО як спостерігача під час роботи Постійної комісії комітету, який створюється для досягнення цілей цієї Конвенції» [17].

Факультативний протокол до Конвениіі про права дитини щзодо торгівлі дітьми, дитячої проституиї цे дитячої порнографї від
01.01.2000 наголошує на необхідності сприяння міжнародного співробітництва між державамиучасницями та національними й міжнародними неурядовими організаціями в цій сфері (ст. 10) [18].

3. Міжнародне екологічне право. Конвениія про охорону біологічного різноманіття від 1992 року в ст. 23 зазначає, що «урядові або неурядові міжнародні організації, які мають досвід у галузях щодо збереження і сталого використання біологічного різноманіття, які поінформували секретаріат про своє бажання бути представленими як спостерігачі на засіданні Конференції, якщо проти цього не суперечитиме не менше ніж одна третина присутніх на засіданні сторін, можуть бути присутні на засіданні» [19].

Рамкова конвенція ООН про зміну клімату від 1992 року серед обов'язків держав, згідно зі ст. 4, передбачає заохочення співпраці та участі НУО у сфері освіти, підготовки кадрів і просвітницької діяльності серед населення 3 питань клімату, а Конференція, відповідно до ст. 7, може використовувати інформацію від НУО та надавати їм статус спостерігача [20].

Конвениія про доступ до інформачіï, участь громадськості в процеесі прийняття рішень $i$ доступ до правосуддя з питань, що стосуються довкілля, від 1998 року (Орхуська Конвенція). У статті 10.5 зазначено: «Будь-яка неурядова організація, компетентна в питаннях, яких стосується ця Конвенція, і яка поінформувала Виконавчого секретаря Європейської економічної комісії про своє бажання бути представленою на нараді Сторін, має право на таку участь зі статусом спостерігача, якщо проти цього не заперечуватиме принаймні одна третина Сторін, присутніх на нараді» [21].

4. Міжнародне кримінальне право. Конвенція ООН проти трансначіональної організованої злочинності від 15.11.2000. У статті 32 цієї Конвенції передбачено співробітництво 3 відповідними неурядовими організаціями. Протокол про запобігання $і$ припинення торгівлі людьми, особливо жінками й дітьми, і покарання за неї, щзо доповнюе Конвениію ООН проти транснаціональної організованої злочинності, націлено на співпрацю 3 НУО для надання допомоги жертвам (ст. 6), для здійснення політики щодо запобігання торгівлі людьми (ст. 9) і для підготовки кадрів (ст. 10) [22].

Протокол про поправки до Єдиної конвенції про наркотичні засоби від 1961 року в ст. 6 серед заходів, що забезпечують виконання Конвенції, закріплюють можливість ініціювання консультацій на підставі інформації, отриманої від НУО, яка $\epsilon$ компетентною в цій сфері та має консультативний статус при ЕКОСОР [23].

Міжнародно-правова відповідальність $є$ також важливим аспектом у механізмі міжнародно-правового регулювання діяльності МНУО. На думку В.А. Мазова, міжнародно-правова відповідаль- 
ність - це сукупність міжнародно-правових відносин, що виникають у сучасному міжнародному праві у зв'язку з правопорушеннями, що їх здійснюють будь-які суб'єкти міжнародного права [24, с. 10]. Міжнародно-правовими підставами для відповідальності МНУО є міжнародні договори в конкретних сферах міжнародного права, зокрема Міжнародна конвенція про відповідальність операторів ядерних суден від 25 травня 1962 року, Віденська конвенція про цивільну відповідальність за ядерну шкоду від 21 травня 1963 року тощо.

Як зазначалося вище, ще одним способом міжнародно-правового регулювання діяльності МНУО є їх саморегулювання. Ідеться про те, що 3 метою регулювання своєї діяльності НУО самостійно розробляють і приймають кодекси поведінки. Кодекси поведінки $€$ найпоширенішою моделлю саморегулювання, які, як правило, приймають організації громадянського суспільства. Кодекс поведінки або етики - це набір стандартів, принципів і рекомендацій з поведінки, які розроблені НУО та яких необхідно чітко дотримуватися. Інакше кажучи, ці кодекси затверджують права й обов'язки НУО. До показових прикладів таких кодексів можемо зарахувати:

Кодекс етики та поведінки Всесвітньої асоціачії неурядових організацій, ініційований у 2002 році на Конференції з питань культури відповідальності й ролі НУО у Вашингтоні. Створення Кодексу завершено у 2005 році, але при цьому Кодекс постійно доповнюється. Він зачіпає широкий спектр питань, включаючи, наприклад, прозорість і звітність, якісне управління, довіру громадськості, людські ресурси та права людини. У 2009 році на додаток до Кодексу розроблено Керівництво з відповідності, яке слугує як контрольнийперелікщодовідповідностіключовимпринципам і стандартам, що прописані в Кодексі [25].

Хартія відповідальності міжнародних неурядових організацій є документом, що містить міжнародні стандарти звітності, прозорості й ефективності НУО, який розроблений групою НУО у 2006 році. Хартія визначає три основні цілі: підвищення якості звітності МНУО; упорядкування стандартів звітності МНУО в різних секто- pax і регіонах; підвищення ефективності МНУО за допомогою обміну досвідом.

Хартія заснована на 10 ключових стандартах: 1) повага прав людини; 2) незалежність; 3) прозорість; 4) якісне управління; 5) відповідальність адвокації; 6) участь; 7) різноманіття/інклюзія; 8) відповідальність щодо навколишнього середовища; 9) етичний фандрейзинг (збирання коштів); 10) професійний менеджмент. Усі члени Хартії беруть на себе зобов'язання подавати щорічні звіти щодо своєї діяльність, які розглядаються Оглядовою Колегією на відповідність певним стандартам. На цей момент до Хартії приєдналося 23 міжнародних і безліч національних НУО [26]. Отже, Хартія відповідальності свідчить про те, що міжнародні НУО прагнуть зберегти прихильність до прозорості й підзвітності своєї діяльності, а також високо цінують довіру та підтримку з боку громадськості.

Висновки та перспективи подальших розвідок у цьому напрямі. Отже, ми дійшли висновку, що МНУО натепер не мають універсальної міжнародної правосуб' єктності, оскільки не мають права схвалювати норми міжнародного права. Проте вони володіють спеціальною, інакше кажучи, функціональною, фрагментарною, факультативною міжнародною правосуб'єктністю, яка виключає здатність нормотворення, проте має виключно правозастосовувальний характер. Інформація про НУО в текстах міжнародних договорів набула поширення лише у 80-90-х рp. ХX ст. Основна кількість міжнародних договорів указує на такі аспекти регулювання, як співпраця держав чи ММУО з НУО з метою отримання від останніх інформації; координація зусиль; надання статусу спостерігача на засіданнях органів, які визначені цими договорами. Міжнародні договори в більшості випадків закріплюють не суб' єктивні права НУО, а їхні обов'язки чи рекомендації державам щодо звернення до НУО за допомогою в тій чи іншій сфері міжнародної діяльності. МНУО $є$ невід'ємним елементом механізму міжнародноправового регулювання, проте відсутність у них нормотворчої функції $\epsilon$ головною перешкодою у визнанні статусу суб'єкта міжнародного права.

\section{СПИСОК ВИКОРИСТАНИХ ДЖЕРЕЛ:}

1. Чернявська Л.Н. Суб'єктність міжнародних неурядових організацій у світовій політиці : автореф. дис. ... канд. політ. наук : 23.00.04. Київ, 2007. 20 с.

2. Тарасов О.В. Міжнародні неурядові організації в системі світового громадянського співтовариства : автореф. дис. ... канд. юрид. наук : 12.00.11. Київ, 1995. 19 с.

3. Килимник І.І., Домбровська А.В. Конспект лекцій із навчальної дисципліни «Міжнародне право» (для студентів денної та заочної форм навчання усіх спеціальностей університету) / Харків. нац. ун-т міськ. госп-ва ім. О.М. Бекетова. Харків : ХНУМГ ім. О.М. Бекетова, 2018. 64 с.

4. Міжнародне публічне право : підручник / за ред. В.М. Репецького. Київ : Знання, 2011. 437 с.

5. Камінська Н. Тенденції розвитку міжнародної правосуб'єктності: теоретичний аналіз. Публічне право. 2014. № 3 (15). С. 92-99. 
6. Делінський О.А. Міжнародна правосуб'єктність: концептуальні підходи до визначення та розуміння. Актуальні проблеми держави і права. 2011. Вип. 62. C. 496-504. URL: http://nbuv.gov.ua/UJRN/ apdp_2011_62_68.

7. Грабинський М.І. Сучасний погляд на суб'єктів міжнародних економічних правовідносин. Науковий вісник публічного та приватного права. Київ, 2016. № 4. С. 277-281.

8. Цимбрівський Т.С. Доктринальні підходи до дослідження правосуб'єктності у міжнародному праві. Науковий вісник Львівського державного університету внутрішніх справ. Серія «Юридична». 2012. № 2 (1). C. 91-100.

9. Білорус І.О. Правосуб'єктність міжнародних неурядових організацій в умовах глобалізації міжнародного економічного права : дис. ... канд. юрид. наук : 12.00.11 / Українська академія зовнішньої торгівлі. Київ, 2005. 219 c.

10. Подшибякин С.А. Правовой статус международных неправительственных организаций : дисс. ... канд. юрид. наук : 12.00.10. Москва, 2004. 158 с.

11. Ільницька У. Особливості міжнародно-правової суб'єктності неурядових організацій. Українська національна ідея: реалії та перспективи розвитку. 2012. Вип. 24. С. 84-91. URL: http://ena.lp.edu.ua/bitstream/ ntb/13495/1/16_84-91_Vyp_24_Nac-idea.pdf.

12. Конвенція про захист прав людини і основоположних свобод. URL: https://zakon.rada.gov.ua/laws/ show/995_004.

13. Європейська конвенція про визнання юридичними особами міжнародних неурядових організацій. URL: https://zakon.rada.gov.ua/laws/show/994_683.

14. Фундаментальні принципи щодо статусу неурядових організацій в Європі. URL: https://zakon.rada.gov.ua/ laws/show/994_209.

15. Женевські конвенції про захист жертв збройних конфоліктів від 12.08.1949. URL: https://zakon.rada.gov.ua/ laws/show/995_154.

16. Конвенція про заборону застосування, накопичення запасів, виробництво і передачу протипіхотних мін та про їх знищення. URL: https://zakon.rada.gov.ua/laws/show/995_379?lang=uk.

17. Європейська конвенція про здійснення прав дітей від 25.01.1996. URL: https://zakon.rada.gov.ua/laws/ show/994_135.

18. Факультативний протокол до Конвенції про права дитини щодо торгівлі дітьми, дитячої проституції і дитячої порнографії. URL: https://zakon.rada.gov.ua/laws/show/995_b09/.

19. Конвенція про охорону біологічного різноманіття від 1992 року. URL:https://zakon.rada.gov.ua/laws/ show/995_030.

20. Рамкова конвенція ООН про зміну клімату від 1992 року. URL: https://zakon.rada.gov.ua/laws/ show/995_044.

21. Конвенція про доступ до інформації, участь громадськості в процесі прийняття рішень та доступ до правосуддя з питань, що стосуються довкілля. URL: https://zakon.rada.gov.ua/laws/show/994_015.

22. Конвенція ОOH проти транснаціональної організованої злочинності. URL: https://zakon.rada.gov.ua/ laws/show/995_791.

23. Протокол про поправки до Єдиної конвенції про наркотичні засоби. URL: https://zakon.rada.gov.ua/laws/ show/995_881.html.

24. Мазов В.А. Ответственность в международном праве. Москва : Юрид. лит., 1979. С. 10.

25. Кодекс етики та поведінки Всесвітньої асоціації неурядових організацій. URL: http://www.wango.org/ default.aspx.

26. Хартія відповідальності Міжнародних неурядових організацій. URL: http://www.ingoaccountabilitycharter. org/. 